INTERDISCIPLINARIA ARCHAEOLOGICA NATURAL SCIENCES IN ARCHAEOLOGY

\title{
The Introduction of the Potter's Wheel to Ancient Sudan
}

\author{
Sarah K. Doherty ${ }^{1^{*}}$ \\ ${ }^{1}$ Department of Continuing Education, University of Oxford, Rewley House, 1 Wellington Square, Oxford, OX1 2JA, United Kingdom
}

\section{A RTICLE INFO}

\section{Article history:}

Received: $1^{\text {st }}$ February 2021

Accepted: $12^{\text {th }}$ November 2021

DOI: http://dx.doi.org/10.24916/iansa.2021.2.14

Key words:

potter's wheel

Middle-Late Bronze Age

ceramics

Sudan

Egypt

colonisation

\begin{abstract}
$A B S T R A C T$
Doherty (2015) has previously investigated the origins of the potter's wheel in Egypt in depth. However, how the potter's wheel came to be used in Sudan has not yet been properly analysed. This paper will present the author's initial investigations into the pottery industry of Sudan and the manufacturing techniques employed by Sudanese potters.

Evidence seems to suggest that rather than being an indigenous invention, the potter's wheel came to Sudan as part of the colonisation of Sudan by Egypt during the Middle-Late Bronze Age. Throughout this period, various Egyptian towns were founded along the river Nile. One such town was Amara West (inhabited c. 1306-1290 BC).

By the Middle Bronze Age, Sudanese potters had well-developed pottery techniques, principally coil- and slab-building. Amara West and other Egyptian colonies used the by then well-established wheel-throwing and coiling techniques (RKE) to manufacture their pottery, principally imported from Egypt. However, these colony towns contained both Sudanese and Egyptian vessels, sometimes in the same contexts, and occasionally with blended manufacture techniques and decoration. This paper will endeavour to postulate upon the effect and legacy of the imposed technology of the potter's wheel on the Sudanese pottery industry.
\end{abstract}

\section{Introduction: The potter's wheel in Egypt}

The potter's wheel is now generally considered to have originated in Mesopotamia in the $5^{\text {th }}$ millennium $\mathrm{BC}$ and subsequently its use spread to the Levant and Egypt (Baldi and Roux, 2016; Freestone and Gaimster, 1997, p.15; Kuhrt, 1995, p.22; Pollock, 1999, p.5; Simpson, 1997, pp.50-55). The potter's wheel came to Egypt before Sudan, during Egypt's $4^{\text {th }}$ dynasty c. 2600 BC, with the invention of the wheel originating in the Near East c. 4500-3800 BC (Doherty, 2015). Recent research by Baldi and Roux (2016, pp.236253) postulated two independent centres of potter's wheel invention in northern Mesopotamia and southern Levant, resulting from a mutual demand for ceremonial vessels. How the pottery wheel was adopted and developed in Egypt was the topic of the author's $\mathrm{PhD}$ research, now published as "The Origins and Use of the Potter's wheel in ancient Egypt" (Doherty, 2015). Like Baldi and Roux (2016), Doherty (2015) also revealed that the initial use of the potter's wheel

*Corresponding author. E-mail: Skdoherty28@msn.com in Egypt was for manufacturing small ceremonial vessels. The potter's wheel was arguably the most significant machine introduced into Africa, second only perhaps to the lever and loom. Shapes noted in the natural world inspired most ancient inventions. However, wheels do not exist in nature, and so can be viewed entirely as a human-inspired invention. The impact of this innovation would not just have affected the potters themselves through the learning of a new skill, but it also signalled the beginnings of a more complex and technologically advanced nation. The use of machinery would have almost certainly required some form of elite sponsorship to instigate the use of the new technology, and perhaps elite monopoly of the products that the machine was used to make (in this case wheel-thrown or wheel-coiled pottery) prior to it being more widely available. The sponsorship sources would have come from the royal court (Papazian, 2005, p.76) or temples (Janssen, 1975, p.183). This seems to be the case particularly for the Egyptians as the Egyptian hierarchical structuring of Dynastic times is thought to have been quite rigid and controlling of the lower status members of society (Shaw, 2004, pp.12-24). 


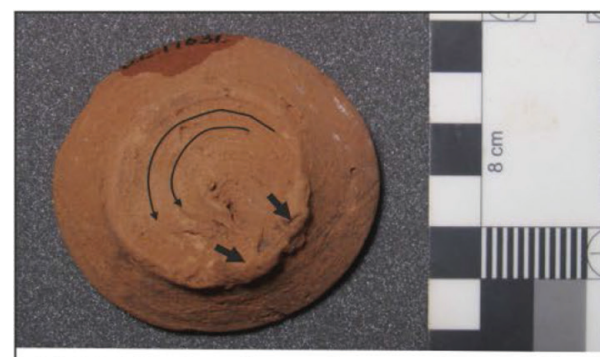

UC 17631 showing string-cut base while wheel rotated, two of the string drag lines highlighted. Note the slight bulging of clay as the vessel was removed from the wheel

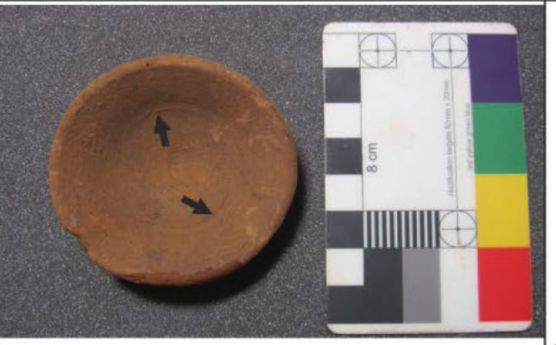

UC 17631 showing interior rilling with a slight torsion well in the center

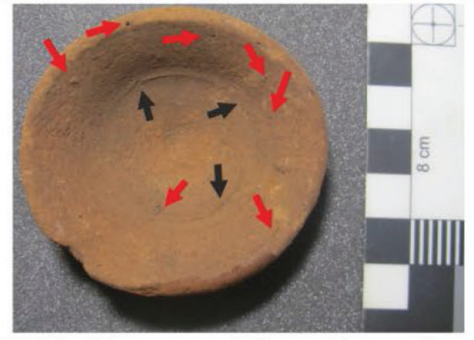

UC 17631 Close up of fingertip marks and rilling lines (black), no coils are present but there are inclusions of small pebbles and chaff blow-outs (in red)

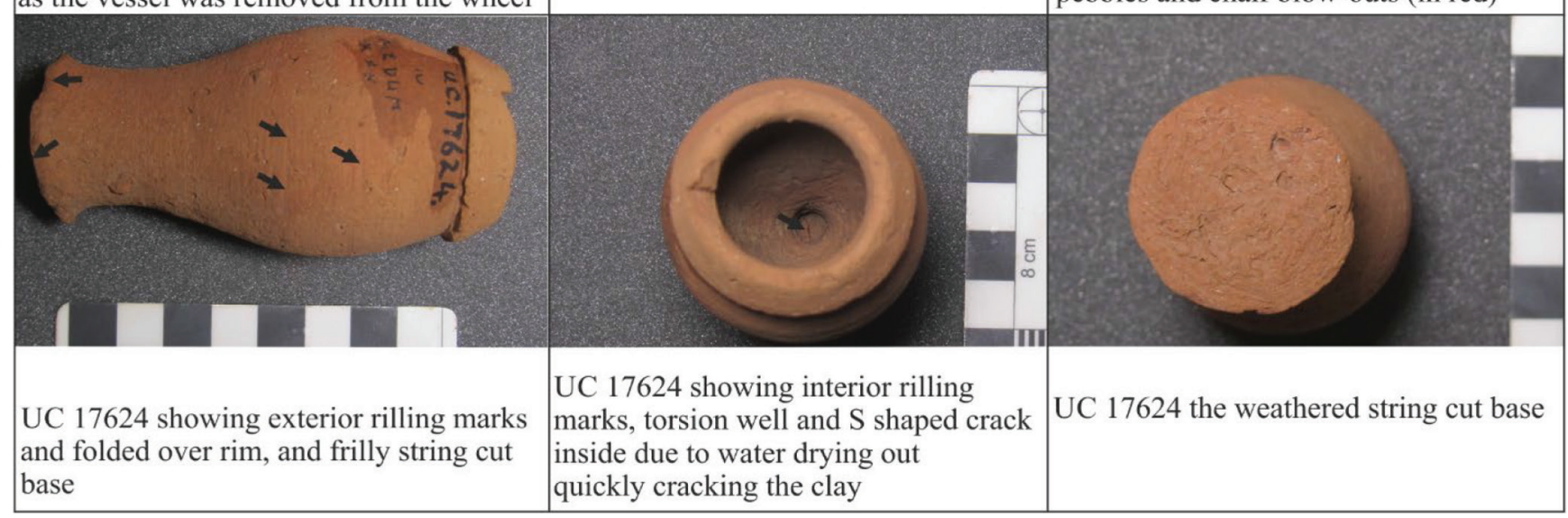

Figure 1. Miniature vessels from the foundation deposit of Pharaoh Sneferu's pyramid at Medum dating to circa $2600 \mathrm{BC}$ with manufacturing details highlighted. These are remarkably similar to those throwing traces identified in throwing off the hump experiments by Caloi (2019). Vessels photographs are a courtesy of the Petrie Museum of Egyptian Archaeology, UCL.

After a few false starts (Doherty, 2015, pp.55-57) the Egyptians adopted the invention of the potter's wheel from Near Eastern potters during the reign of Pharaoh Sneferu (c. $2600 \mathrm{BC}$ ), the father of the famous Khufu or Cheops. Levantine potters had been using the wheel to delicately thin and finish coil-built vessels, as seen in Tell Yarmuth, Israel and other sites across the Levant (Courty and Roux, 1995; Roux and de Miroschedji, 2009). Roux and Courty (Roux, 1994; Courty and Roux, 1995; Pierret, 1995; Roux and Courty, 1997) demonstrated that during the earliest use of the potter's wheel, potters did not start wheel-throwing vessels immediately. Rather, they employed pre-existing coiling techniques in combination with rotation on the wheel. There is evidence to suggest that from the start, the Egyptians utilised the Levantine wheel to throw vessels off the hump of clay rather than finish wheel-coil-built vessels, at least for the very small "miniature" vessels (Allen, 2006, pp.19-26; Bárta, 1995; Doherty, 2015, pp.66-69). However, throwing off the hump has, as yet, been undetected in other larger contemporary vessel types, so further work is required. The initial evidence suggests that potters began making small pieces on the wheel, in the same manner as apprentice potters do, fashioning miniature offering pots about $7-8 \mathrm{~cm}$ in height (Roux and Corbetta, 1989, pp.11-24). Interestingly, these potters appear to have been state-sponsored, as these first wheel-made vessels solely occur in elite cemetery sites and are encountered in all the Old Kingdom great pyramid sites (Bárta, 1995, pp.15-24; Charvát, 1981; Doherty, 2015, p.67; el-Khouli, 1991; Reisner, 1931). These vessels exhibit similar traces to those seen in wheel-coiled vessels, but without traces of coils as they are very small. This may mean that the Egyptian potters used very small coils of clay employing wheel-coiling which are now undetectable to the ceramicist. The use of very small coils is inefficient and difficult to achieve on a wheel. Alternatively, the potters were beginning the first steps into throwing off the hump and learning the techniques of manipulating and centring a mass of clay. The wheel would have been spun with one hand, and the clay manipulated with the other, resulting in initially the centring of the clay, and the drawing up and opening out and shaping of these miniature vessels. When the Egyptians began to utilise the wheel for larger vessels, they appear to have used the wheel-coiling technique as noted in Levantine and Mesopotamian contexts (Roux and Baldi, 2016). The Egyptians were clearly aware of the wheel-coiling technique as V-shaped bowls in Nile Clay have been uncovered at the site of Buto in the Delta (Dessel, 2009, pp.100-101; Faltings, 1998a, p.23; 1998b, pp.367-369).

Some of the earliest examples of these miniature vessels were uncovered from the foundation deposit of Pharaoh Sneferu's pyramid at Medum (Petrie, 1892, Plate XXX; Petrie, Mackay and Wainwright, 1910, Plate XXV, Figure 1). These show traces similar to those identified in throwing off the hump experiments on ceramics at Phaistos 


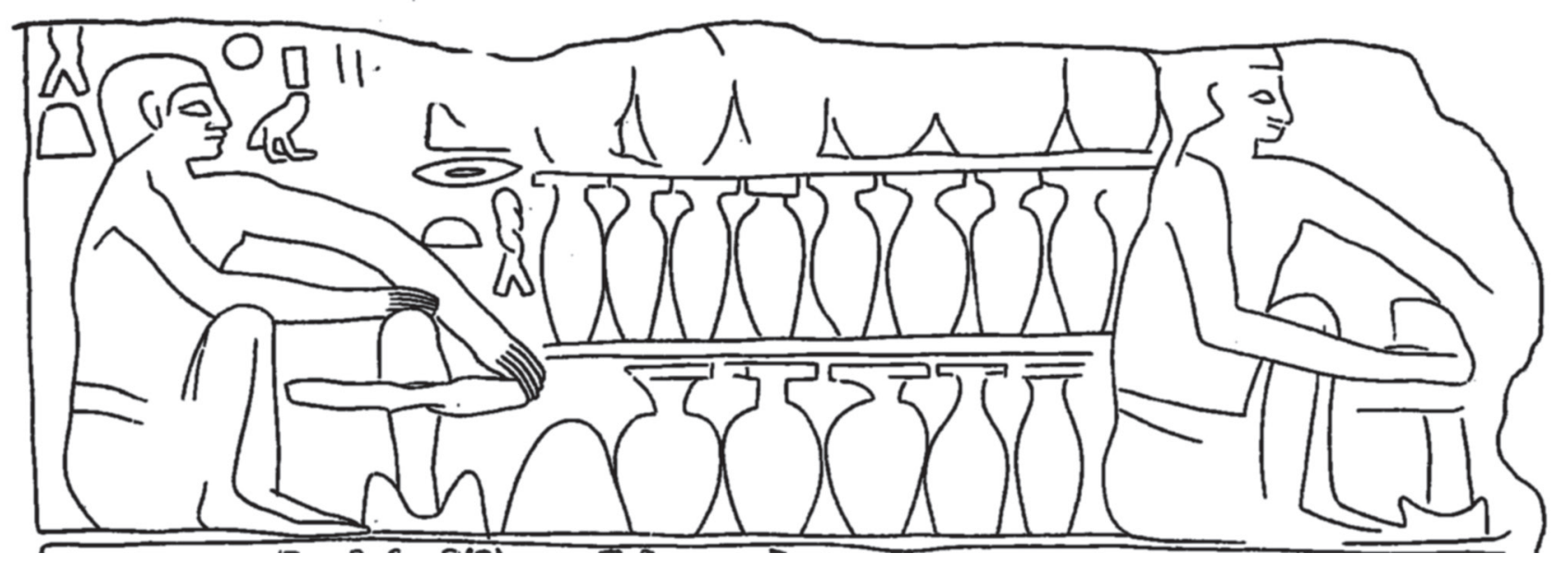

Figure 2. Potters centring clay on wheel from the Tomb of Khentika/Ikhekhi, Saqqara, Teti Cemetery (After Holthoer, 1977, pp.8-9; James and Apted, 1953, Plate XLII: XII [244]).

recently published by Caloi (2019, pp.14-16). Like the Phaistian plain handleless cups, the Egyptian miniature vessels are: (1) small (the plates are $>4 \mathrm{~cm}$ in height, and jars $>8 \mathrm{~cm}$ ); (2) of standard measurements ( $\max 8 \mathrm{~cm}$ tall and $6.5 \mathrm{~cm}$ in diameter; (3) of similar profiles on both the plates and jars; (4) with a deep hollow or well in the interior base; (5) with clearly visible throwing marks on the interior and exterior; (6) with poorly-executed or finished surfaces; and (7) mass-produced - some 10,000s were uncovered at the pyramid of Dashur (Fakhry, 1961, p.135). There are also additional traces such as string cutting marks, clay bulges where the pot was removed from the wheel, and sticky finger impressions.

Further supporting the use of throwing off the hump at this early date can be noted in the $6^{\text {th }}$ dynasty Tomb of Khentika/Ikhekhi at Saqqara, which depicts two potters preparing clay by centring it on the wheel before it would be later shaped into a vessel (Figure 2). A mound of clay is positioned in front of one potter who uses the side of his hand to press down onto the cone of clay and begin the centring process. Some of the finished pots are shown on shelves between them. Later depictions such as the Middle Kingdom tombs of Bakt III and Amenemhat at Beni Hassan (Holthoer, 1977, p.12, Figure 14; Doherty, 2015 p.27, Figure 3.6; Newberry, 1893, pp.30-31, Plate XI) also depict at least four potters throwing off the hump. This process of using a cone-shaped mound of clay makes centring easier, and enables the potter to utilise the weight of the lump of clay to increase the momentum of the wheel (Rice, 1987, p.129). This system is still in use by the potters of el-Fustat in Cairo where several standard sized pots are thrown from the same lump (Van der Kooij and Wendrich, 2002, p.150).

Despite the introduction of the potter's wheel from the $4^{\text {th }}$ dynasty in Egypt for producing miniature vessels, other techniques of hand-building and -coiling were not forgotten. Most medium-large dynastic jars ${ }^{1}$, such as beer jars, were

\footnotetext{
${ }^{1}$ I use Wodzińska (2009) terminology for Egyptian dynastic pottery types.
}

made through coiling, bread moulds were formed over a core or patrix, while large platters and bread trays were finger moulded and pinched (Bourriau, 1981, pp.17-23). Jars, bowls, and plates continued to be coil-built or wheelcoiled until the First Intermediate Period (c. 2181-2025 BC). Though as Bourriau (1981, p.15) suggests, this may have been later in the Second Intermediate Period (2040 $1551 \mathrm{BC})$. After this point, almost all pottery types, with the exception of coarse wares and some of the largest amphorae, were wheel-coiled (or possibly thrown, although more work is needed). The Egyptians formed pottery using clay recipes of both Nile Silt, gathered from the edges of the river Nile, and Marl clays, mined from desert regions mostly to the East or along the Nile Valley between Esna and Cairo (Bourriau et al., 2000b, p.121), and sometimes a mixture of the two. The clays were then mixed with chaff, pebbles and, in some cases, grog to the particular recipes of the potter (Bourriau, 1981, pp.14-15; Bourriau et al., 2000a). The clays were usually gathered from one source and pottery workshops seem to have produced either Silt or Marl clay wares (Nordström and Bourriau, 1993, p.166; Bourriau et al., 2000b, p.122), with some exceptions, e.g., at Hierakonpolis (Allen et al., 1982, pp.199-212; Allen, 1989).

\section{Egyptian Colonisation of Sudan}

By the beginning of the second millennium $\mathrm{BC}$, the second to fourth cataracts of the Nile in North Sudan were occupied by several Kushite polities associated with the city of Kerma and the C-group, with vassal polities around the island of Sai (Edwards 2004, pp.78-79). From about 2000 BC, the Egyptians began a military campaign to conquer Nubia, eager to own the gold mines and other wealth that the Nubians possessed (D'Ercole et al., 2017; Graves, 2010, Figure 3). The Egyptians conquered Lower Nubia, the entire reach between the first and second cataracts of the Nile, at the beginning of the Middle Kingdom (c. 2050 to 1710 BC). One should 
Table 1. Relevant Chronology (after Edwards 2004).

\begin{tabular}{llll}
\hline DATE BC & EGYPTIAN DYNASTY & LOWER NUBIA & UPPER NUBIA \\
\hline $2050-1650$ & Middle Kingdom (11-13) & C-Group & Middle Kerma \\
$1650-1550$ & Second Intermediate (14-17) & C-Group & Classic Kerma \\
$1550-1050$ & New Kingdom (18-20) & C-Group & Recent Kerma \\
$1050-750$ & Third Intermediate (21-24) & Uncertain & Pre-Napata \\
$750-332$ & Late Period (25-30) & Uncertain & Napata \\
$332-$ c AD 300 & Ptolemaic and Roman & & Meriotic \\
\hline
\end{tabular}

not consider Nubia as "one culture" but as "various Nubias" of disparate groups, each with different social structures and different approaches to adapting and adopting Egyptian colonisation and the associated goods (Edwards, 2004, pp.78-81; O'Connor, 1991; 1993). These "various Nubias" and their different political structures (and the potential for local rebellion) was perhaps why the construction of thirteen Egyptian fortresses was deemed necessary by the reign of Senwosret III (circa 1850 BC) (Edwards, 2004, pp.91-94; S.T. Smith, 1995, pp.51-80; Knoblauch, 2019, pp.367-389). Initially occupied by military personnel, these fortresses suggest that at the beginning of their construction, the architecture and objects used were mostly imported from Egypt. However, there is evidence for an easing or a blending of the two cultures suggested by later changes in building design, cooking and domestic pottery types, and the appearance of elite tombs and stelae. This demonstrated that the Egyptian occupation shifted to permanent settlers in more self-sufficient communities, connecting more with their conquered neighbours at the end of the Twelfth dynasty (circa 1802 BC) (H. Smith, 1976, pp.67-69; S.T. Smith, 1995, pp.51-80).

Some scholars (e.g., Emery et al., 1979) have suggested that some fortresses were abandoned in the late Thirteenth dynasty (circa 1750 BC) due to a Kerman-based Kushite expansion into Lower Nubia. On the other hand, S.T. Smith (1995, pp.81-145) argues for a generally peaceful handover to Kerma control. However, there is evidence suggesting that

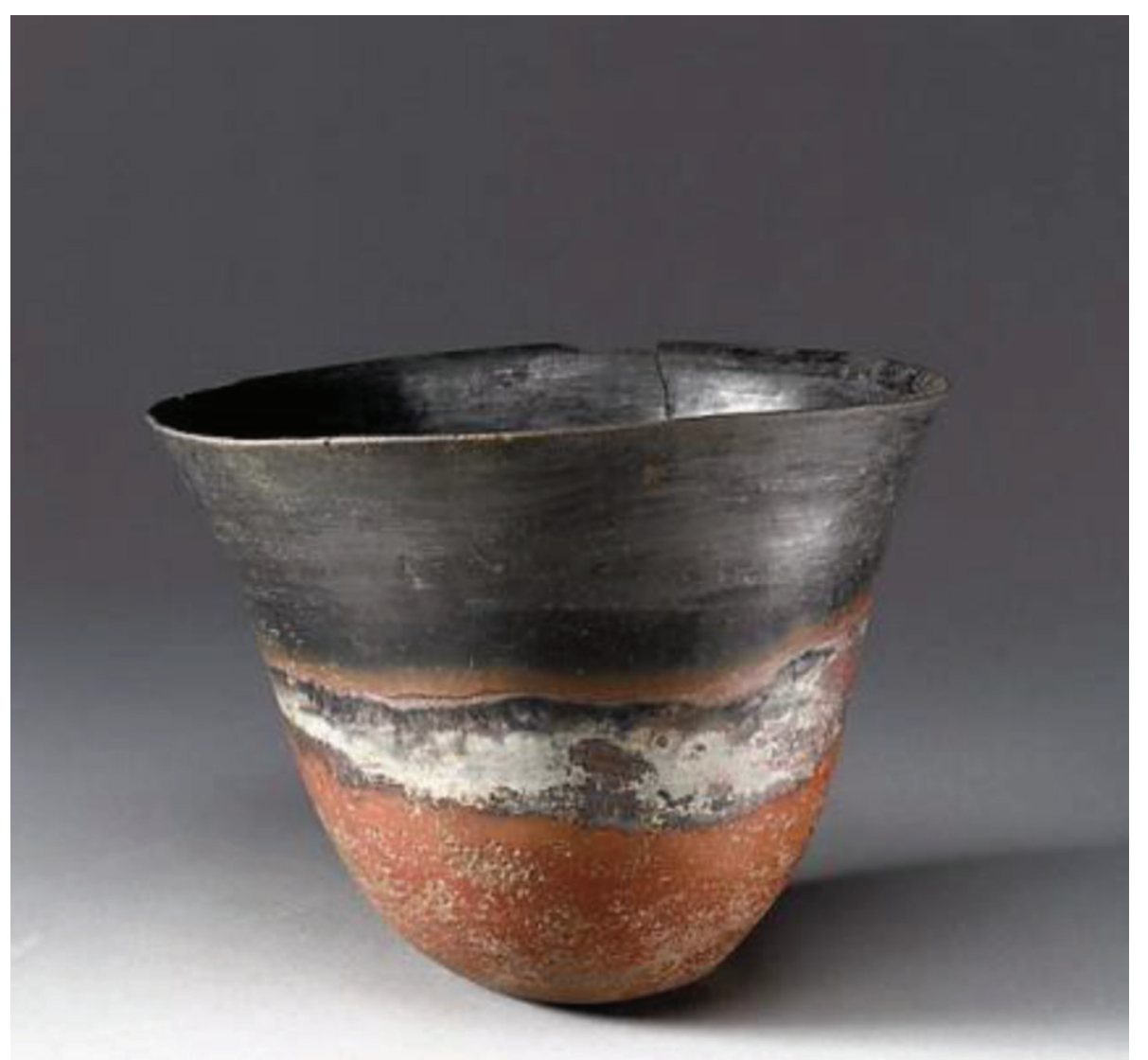

Figure 3. Kerma Beaker with huntite applied as a slip prior to firing to create the silver band effect. From Metropolitan Museum of Art. 20.2.45 (CC0 1.0). Rogers Fund, 1920. Purchased from the Oxford University Expedition to Nubia by the Museum, 1920. Dated to circa $1802-1640$ B.C. 
some fortresses like Buhen and perhaps others were violently attacked later during the New Kingdom (Emery et al., 1979). This period corresponds to when the town of Kerma reached its greatest extent (Bonnet, 1999). From about 750 BC, the Napatan culture emerged around the Dongola Reach with major settlements at Napata, el-Kurru, Nuri and Jebel Barkal. During this time, the Egyptian influence waned after there was a war between Egypt and Kush in 593 BC, when Psammatik II invaded Kush. During the last centuries of the first millennium BC, the Kushite state focused on Meroe in the Shendi reach between the fifth and sixth cataracts. The Meriotic Kingdom gained control of the Middle Nile and its hinterlands (Adams, 1977; Edwards, 2004, pp.122-141; O’Connor, 1993).

\section{Sudanese Pottery circa $2000-1500$ BC}

In general, by circa 2000 BC, Egyptian pottery was wheelthrown or wheel-coiled, whereas Nubian pottery employed hand-building and did not use the wheel yet (Nordström and Bourriau, 1993, p.184; Rose, 2012, p.13 and p.16). Nubian pottery was highly sophisticated, utilising handbuilding techniques and firing styles largely abandoned by the Egyptians by the $4^{\text {th }}$ dynasty (Arnold, 1993, p.17). Construction of vessels was via the paddle and anvil, coiling, pinching, or slab-building techniques, or combinations of these (Bourriau, 1981, p.15). Pots were often decorated with hatching, raised criss-cross mouldings and stamps (Robertson and Hill, 1999, pp.321-330). By the Classic Kerma period (1750-1500 BC), the manufacture of vessels was highly developed. The Kerman potters regularly highly burnished and decorated their wares and made their vessels with remarkably thin walls. These vessels reached their peak in the Kerma beakers with walls as thin as $2-5 \mathrm{~mm}$, highlypolished and fired with great skill (Figure 3 or e.g., Bourriau, 1981, Types 207-208, British Museum 65577). Most vessels were manufactured using Nile Clay, often from a mixture of sources and recipes (Adams, 1962, p.249).

In terms of the difference in firing techniques, Egyptian pottery was fired in box or updraught kilns, while most Nubian pottery was produced in bonfires (Bourriau et al., 2000b, p.128; Gratien, 2000, p.114). Classic Kerman potters in particular were extremely skilful in utilising the oxidising and reduction conditions of pit firing. Experiments by Doherty (forthcoming) postulates that the Kerman potters applied the white carbonate mineral huntite $\mathrm{Mg}_{3} \mathrm{Ca}\left(\mathrm{CO}_{3}\right)_{4}$ to their beakers as a slip prior to firing to produce a beautiful white-silver band (Figure 3). Sources of huntite are attested in the Persian Gulf (Kinsman, 1967, pp.1332-1340) and Tunisia (Perthuisot, 1971, pp.185-188) and have been detected within pigments in Egyptian tomb scenes and coffins (Blom-Böer, 1994, p.67 and p.76; Lee and Quirke, 2000, pp.114-115). While utilised in funerary architecture and furniture, huntite was never employed by the Egyptians when they made their black-topped pottery during the Predynastic Period.

\section{The Egyptian Colonisation of Sudan and its effects on pottery}

Evidence from the excavations of the different fortresses suggest that at the beginning of the Egyptian military campaigns the soldiers brought with them all the objects and trappings from home that they required to establish themselves, including pottery vessels filled with foodstuffs. In particular, the presence of pottery made from marl clays in Sudan is important (labelled as "drab ware" by Reisner at the Egyptian colony excavations at Kerma (Reisner, 1924, pp.320-321 e.g., BM EA65586)). Such marl clays were mostly not employed by Kerman potters, as there are limited supplies in Sudan. This implies that ceramic vessels were regularly imported from Egyptian workshops in both Upper and Lower Egypt (Spencer, 2002, pp.13-32). However, large-scale pottery production of Egyptian-style, Nile Silt vessels have been excavated at the fortresses of Mirgissa and Serra East during the Middle Kingdom which suggests that most of this pottery was produced locally in Nubia (Williams et al., 1993; Williams, 2017, pp.309-322; Vercoutter, 1966, pp.276-283; 1970). There is also evidence of at least bread moulds being manufactured at the fortress of Buhen, where a ceramic dump outside the inner walls of Block $\mathrm{H}$ by the temple area revealed 1015 bread moulds (of the 5535 found at Buhen) (Emery et al., 1979, pp.175-176; Graves, 2010, p.23). Therefore, the Egyptians were evidentially quite selfsufficient for at least the Nile Silt vessels.

Later period Egyptian colonies were found by excavators to have a mixture of Nubian and Egyptian pottery, as well as other "Sudanese style" objects being used in Egyptian colonies. Funerary customs such as beds, intermarriage, cultural permeability, and shifting identities led to a blending of the two cultures, neither totally Egyptian nor Nubian. One such site is Amara West, recently excavated by teams from the British and Khartoum Museums (Spencer et al., 2014; N. Spencer, 2017), and previously by the Egypt Exploration Society (P. Spencer, 2002). Amara West was the administrative capital of Upper Nubia $\left(19^{\text {th }}-25^{\text {th }}\right.$ dynasty, $1550-656 \mathrm{BC})$. The site is located on the west bank of the Nile between the second and third cataracts in northern Sudan. The mudbrick-walled garrison town is comprised of densely-packed mudbrick buildings, including largescale storage places, houses of various sizes (from 50 to $500 \mathrm{~m}^{2}$ ) and structures of unclear function (N. Spencer, 2017; P. Spencer, 2002; Spencer et al., 2014). Some of the architecture and objects uncovered at Amara West suggest an intriguing blending of Egyptian and Nubian cultures. For example, N. Spencer (2017, p.465) cites a Nubian style ovoid structure E12.11 discovered at Amara West with both $20^{\text {th }}$ dynasty Egyptian and Nubian pottery discovered within it (Spataro et al., 2014). This circular building echoes the "great hut" at Kerma (Bonnet, 1996, pp.32-34, Figure 7, Plate 10) and similar buildings at Dokki Gel (Bonnet, 2008, v-vi), Kawa (Welsby, 2001, pp.64-66, Plate 1) and Kulubnarti (Adams, 1994, pp.236-7, Maps 7.4 and 7.5). At other Egyptian colonies, excavators are increasingly 
uncovering Nubian sherds alongside Egyptian sherds within domestic settings, as well as in funerary pyramids and tombs. These colonies have some examples of kilns and Nile silt wasters, but identified pottery workshops are relatively rare. Two exceptions, as mentioned above, are at the Egyptian fortresses of Mirgissa and Serra East (Williams et al., 1993; Vercoutter, 1966, pp.276-283; Vercoutter, 1970).

It appears that the Egyptians allowed access to their pottery skills and were interested in producing selfsufficient colonies in Sudan, and working with acculturated indigenous groups to produce a variety of crafts, including pottery industries. Petrographic analyses of the clays utilised by Nubian and Egyptian potters demonstrate that prior to the Egyptian colonisation, the Nubian clays were mixed, whereas the Egyptian clays were more homogenous (Carrano et al., 2008, pp.95-96). The diversity of chemical signatures from Nubian pottery suggests that these pots were being made on a smaller scale than the Egyptian, likely by part-time potters who were exploiting a range of clay sources. However, once Egyptian colonisation began, there is evidence that Egyptian and Nubian silt wares were made from the same clay sources in Sudan. This suggests that colonial communities were not entirely reliant on trade with Egypt itself to supply manufactured goods. Moreover, the apparent lack of change in ceramic composition throughout the New Kingdom and early Napatan period demonstrates that there was no wholesale rejection of Egyptian-style manufacturing techniques with the gradual decline in imperial power. Together, this evidence supports at least limited acculturation once the Egyptians left Sudan (Carrano et al., 2009, pp.785-797).

The evidence for when the potter's wheel came to be used in Sudan rather than Egyptian imported pottery relates to the form of the clays used in Sudan. So called "gilded wares" are covered with a micaceous (muscovite) slip on both sides, giving the sherd a "golden" appearance. Such fragments were produced in the Second Cataract forts, recently re-studied by Knoblauch (2011, pp.167-183). A rare example comes from the Egyptian site at Elephantine (Budka, 2016a; 2016b; Budka and Doyen, 2013). This small fragment $(3.1 \times 3 \mathrm{~cm})$ of a thin-walled jar with flaring rim made in a very fine Nile Silt (Vienna classification B2, Nordström and Bourriau, 1993, pp.168-182) was found in material below the foundations of a large house, number 55. Most examples of the clay come from the Second Cataract fort sites and in the Kerman cemeteries at Kerma (Bourriau, 2004, p.9), Ukma West (Vila, 1987, p.203) and Sai (Gratien, 1986, Figure 300 EVI). The potters at these fortresses were creating standard Egyptian wheel-coiled wares in Nile silt, but adding a local twist by slipping with the micaceous (muscovite) slip, presumably having brought a potter's wheel with them.

Micaceous clays are an interesting choice, as they are good for creating hard, durable vessels that are resistant to thermal shock (Anderson, 1999, pp.3-5). However, the Egyptian potters working in Sudan seemed to recognise that mica-rich clays are also unsuitable for long-term liquid storage, as the vessels tended to fall apart. They appear to have used mica-rich clays for making tableware rather than cooking pots e.g., globular jars, cups, bowls, spouted vessels with applied animal motifs (Budka, 2016a; 2016b; Budka and Doyen, 2013). This rare, wheel-made Nile clay ware was locally produced in Lower Nubia during the late Middle Kingdom to the Second Intermediate Period (circa 1782-1500 BC), but stopped being created shortly afterwards.

The co-existence of locally-made, Egyptian-style, wheelcoiled cooking pots and Nubian, hand-coiled and paddled ones appears at many Egyptian colony sites (e.g., at Amara West, Garnett, 2014, pp.62-63). Budka (2016b, pp.285-290), however, noted imported Egyptian cooking pots and Nubian cooking pots being used across the settlement areas of Sai, dating to the $18^{\text {th }}$ dynasty, and traced a gradual trend towards local copies in Upper Nubian fabrics from the mid- $18^{\text {th }}$ Dynasty onwards. Sai seems to be the exception to the rule for cooking vessels. Most other colony sites used local Nubian clays to fashion their Egyptian cooking vessels, and increasingly favoured Nubian cooking types as they became more selfreliant. However, there was still a need for some imported Egyptian wares, presumably so they could take advantage of importing the foodstuffs and liquids they contained (Bourriau, 1995, pp.129-144; S.T. Smith 2002, pp.43-79).

\section{The Potter's Wheel in Sudan}

Unfortunately, potter's workshops are extremely rare in both Egypt and Sudan, and evidence of potter's wheels even more so (Doherty, 2020). Egyptian dynastic potter's wheel bearings are very similar to those known across the Levant and the Middle East (Roux, 1994; 2008; 2009; Roux and Courty, 1997; 1998; Roux and de Miroschedji, 2009, pp.155-173). They comprise a socket and pivot of stone, usually limestone, granodiorite or basalt, or a combination as seen in Figure 4 (Doherty, 2015, pp.16-22 and Powell, 1995, pp.310-311, Figure 10.1). The socket would have been buried into the ground, and a wheelhead of unfired clay, wood or terracotta attached to the top of the pivot (Figure 4). The potter would have spun it with one hand and fashioned coils of clay with the other. The concept of the potter's wheel was borrowed from the Levantine neighbours around $2600 \mathrm{BC}$ and was gradually introduced to state-controlled potters (Doherty, 2015, pp.43-69). As suggested above, the miniature wheelthrown vessels were produced exclusively for elite funerary sites, but the pottery repertoires were gradually expanded until almost all pottery vessels were formed on the wheel by about $2100 \mathrm{BC}$, probably by wheel-coiling, although further work is needed. By bringing this new technology to Sudan, the Egyptians were in effect stamping their objects and culture upon the new colonies. Producing Egyptianstyle, thrown vessels required the mastering of an entirely new skill, using the potter's wheel, and one which can take up to 10 years to be truly proficient (Ericsson and Lehmann, 1996, pp.273-305; Roux and Corbetta, 1989). The potter's wheel bearings can be very heavy, with most bearing stones 


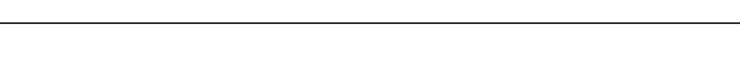
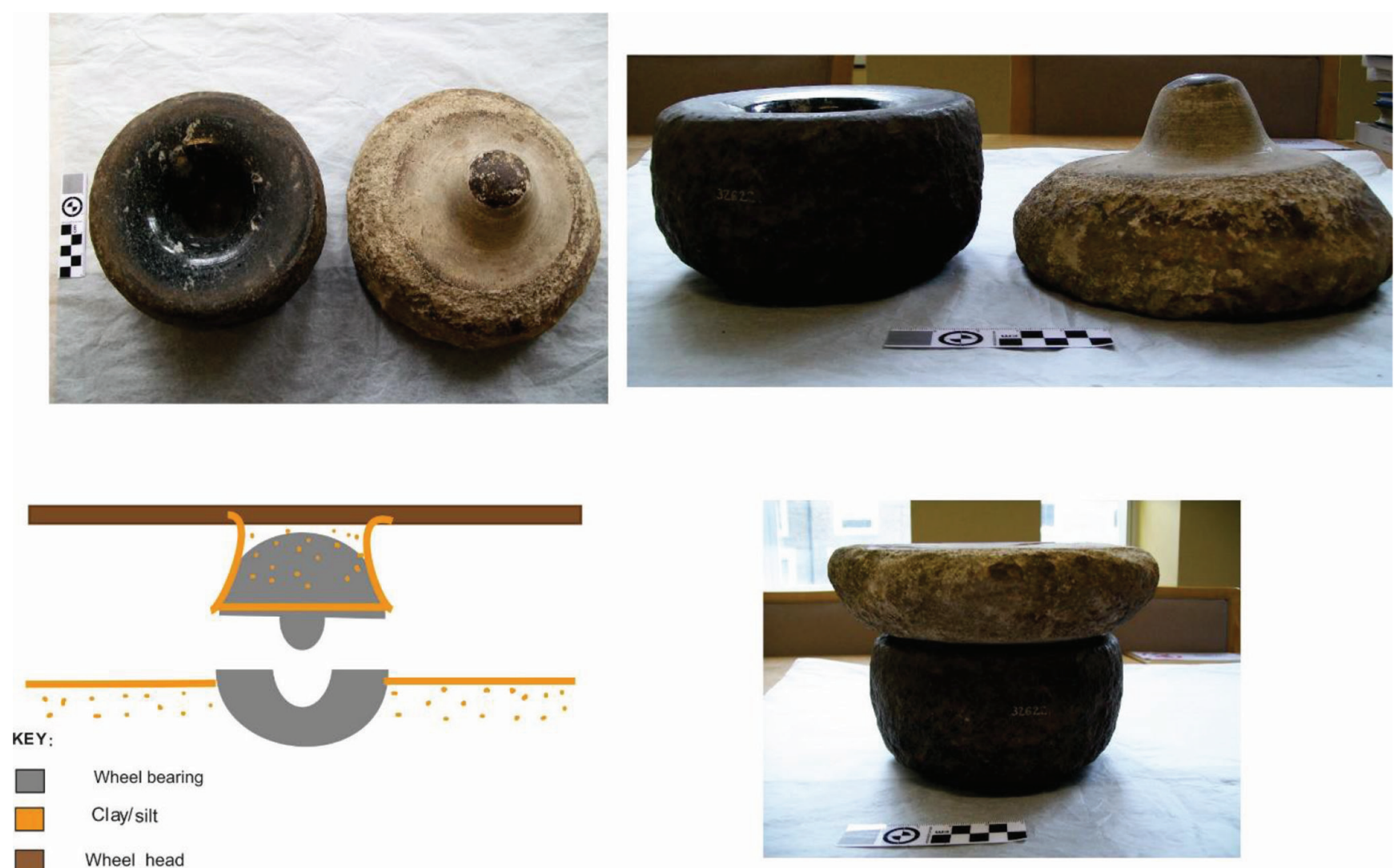

Wheel head

Figure 4. Potter's wheel bearing BM32622 from the British Museum Collection, and sketch of how the wheel bearings would have been arranged with a wheelhead.

weighing between 3 and $7 \mathrm{~kg}$ (Powell, 1995). Transporting these around would have taken some consideration. However, there are several other factors which would need to be in place in order to set up the workshop. There would need to be suitable locations for the machinery, cold and wet places for the clay, open areas to dry and fire the pots, and a market demand for wheel-made pottery. There would also have been the need for sponsorship by an estate owner to provision the estate with suitable vessels or in state-controlled industrial quarters. Archaeological evidence suggests that there was a variety of different types of potter's workshops, from those at the domestic household level (making pinch and coil vessels) through to industrial complexes creating vessels by the tens of thousands for the funerary market using throwing and wheel-coiling techniques (e.g., at Abusir; Verner, 1992, pp.55-59). At any one time, there would have been both domestic and industrial pottery production taking place (Rice, 1897, pp.183-191), which would also have influenced the developing use of the wheel (Bourriau, 2000, pp.141-142).

\section{Potter's Workshops with Wheels in Sudan}

Pottery workshops with wheel bearings or wheelheads are extremely rare in Sudan. An example of a clay wheelhead from a potter's wheel has been recently recognised and published by Stuart Tyson Smith (2014, pp 103-121) from the fortress of Askut, dating to the Middle Kingdom (circa 1850 BC). It was discovered within a storehouse complex, perhaps suggesting state control of production of the craft. Interestingly, it is made of fired terracotta and quite an unusual shape, with finger holes for the wheel to be attached to a pivot with wet clay (S.T. Smith 2014, pp.103121). It was probably designed for the mushroom headed shaped pivot stones (Doherty, 2015, pp.16-22; Figure 4).

The wheelhead's side measured $42 \mathrm{~cm}$ in diameter, much smaller than those thought by Powell (1995, pp.309-335) and the author's own experiences to be useful for throwing. In her experiments, Powell determined that around 70-75 cm unfired clay wheelheads worked best, similar to an example uncovered at the site of Abu Sir, Egypt. This author's experimental reconstructions found that wooden wheelheads of $55 \mathrm{~cm}$ also worked well. With this example, we can add terracotta to the repertoire of wheelhead materials.

In 1977, Holthoer described a Middle Kingdom period pottery workshop, which also may have contained a wheel (Holthoer, 1977, p.16). Site no. 228, dated to the Middle Kingdom (circa $1850 \mathrm{BC}$ ), is a contemporary site to Aksut discovered by the Scandinavian Joint Expedition to Sudan in the 1960s as part of the Aswan High Dam Archaeology Rescue Missions. The wheel was found within Room 7, described as a pivot located near the east wall, lubricated with black resin (Holthoer, 1977, p.16; Säve- Söderburg, 1963). It was located in a workshop, which featured a kiln, 
two small drying bins, and an area with dung and straw probably as fuel for the kiln. Unfortunately, there does not appear to have been any published photographs or drawings of the wheel bearings. All of the pottery sherds uncovered at the workshop were wheel-made, with the exception of one complete hand-built cup, so it is more than likely that this was an Egyptian pottery wheel-coiling (or possibly wheelthrowing) workshop.

The often distinctive potting traditions of Bronze Age "Kush/Nubia" seem to have been, at least temporarily, disrupted during the later second millennium BC, one legacy of Egypt's southwards expansion during the New Kingdom (Lacovara, 1997). A lack of archaeologically recognisable and distinctive "indigenous" ceramic culture(s) over subsequent centuries is in itself of interest. This seems to persist through the first half of the first millennium BC. Not long after the Egyptians abandoned their empire in Nubia during the Third Intermediate Period, the powerful complex indigenous polity of Napata arose. In turn, most of what we encounter in later "Napatan" pottery (see Figure 1) draws heavily on Egyptian production techniques and repertoires (Welsby-Sjöström and Thomas, 2011, pp.64-71).

However, in the Meroitic period (332 BC - circa AD 300) these production techniques were to change markedly, with the appearance of what were in fact often quite new types of pottery (Rose, 1998; Ting and Humphris, 2020, pp.141160). These may have looked to both internal (Sudanic) and external (Mediterranean) traditions, in turn relating to a number of distinct modes of production and technologies. Meroe, located between the fifth and sixth cataracts of the Nile, had become the new capital of the Kushite state by about 270 BC. During the Meroitic period, Kushite culture showed less Egyptian influence and increasingly displayed a Nubian character, including the worship of new local deities and the creation of a Meroitic alphabet. The rule of Meroe's kings extended hundreds of miles to the north, and most of northern Nubia between the first and second cataracts became a Meroitic province (Edwards, 2004, pp.141-181).

The Egyptian-style potter's wheel apparently was one of the items that survived the Egyptians departure from Sudan, and was perhaps a deliberately chosen technology by the Kushite culture (van der Leeuw, 2002). Two other Meriotic pottery workshops (without wheels) have been uncovered at Hamadab (Wolf and Nowotnick, 2006, pp.257-272) and Muweis (Buad, 2008). Some Meriotic wheel-made sherds have been dated to as early as the first half of the third century AD (Lenoble and Sharif, 1992, pp. 626635). At the site of Musawwarat es-Sufra, which dates to the $1^{\text {st }}$ millennium $\mathrm{AD}$, a pottery workshop that included a wheel was discovered in 1965, and reanalysed in 1997 by Edwards (1999). Musawwarat es- Sufra is situated about $180 \mathrm{~km}$ northeast of Sudan's modern capital Khartoum, $25 \mathrm{~km}$ outside of the Nile valley in the semi-arid landscape of the Keraba. The recovery of substantial quantities of finely-decorated kaolinitic finewares, apparently the remains of manufacturing failures, and a significant body of other material relating to pottery manufacturing, including a granite potter's wheel, was identified. The wheel was discovered in a small room (225) in the north of a temple complex known as the Great Enclosure (Näser, 2010a, pp.225-226; 2010b, pp.20-25). In addition, a substantial body of other pottery, much of it thought likely to be locally made, provided valuable new insights into the ceramic culture associated with this very special site. At the same point in time as this pottery workshop was in use, there were a wide variety of handmade wares circulating, particularly in domestic settings, whereas the wheel-made finewares were rarer (Edwards, 1999). This may suggest that the potter's wheel and wheel-made pottery was regarded as an urban specialism, perhaps a "royal monopoly" similar to how iron workers were considered at that time (Ting and Humphris, 2020, pp.141-160; Humphris et al., 2018, pp.291-311). The potter's wheel may have been maintained to just produce finewares for the elites of Musawwarat es- Sufra, as had been the case for the $4^{\text {th }}$ dynasty Pharaohs (Doherty, 2015; Gibli and Remigius, 2012) and in the Levantine city states (Roux, 2008; Roux and de Miroschedji, 2009).

\section{Conclusion}

When building their Middle Kingdom fortresses, the Egyptians attempts to make themselves self-sufficient while there included importing skilled Egyptian potters and their wheels. The Egyptian imperial presence was particularly strong in Lower Nubia, and the archaeological record indicates that at least some aspects of the local Nubian societies were affected by Egyptian influences, and vice-versa. This was particularly the case for pottery. Most Egyptian colony sites contained a mixture of pottery techniques, particularly Nubian handmade cooking pots and Egyptian wheel-coiled vessels initially imported from Egypt, and later made using local clays (Rose, 2019, p.678). Both domestic and funerary contexts demonstrate that there was a blending of cultures. Rather than an independent indigenous invention, the potter's wheel was deliberately brought to Sudan from Egypt and was part of a suite of new Egyptian technologies imposed upon the Sudanese. However, once the Egyptians left, during the Napatan and Meriotic periods, the potters made a deliberate choice to maintain the Egyptian technologies that were useful to them. In doing so they adapted them to their own needs, creating magnificent fineware pottery using kaolinite clays and their own decorative flair.

\section{References}

ADAMS, W.Y., 1962. Archaeological Survey of the West Bank of the Nile. Kush, 10, 10-18.

ADAMS, W., 1977. Nubia: Corridor to Africa. London: Allen Lane.

ADAMS, W.Y. 1994. Kulubnarti I. The Architectural Remains. Lexington: Program for Cultural Resource Assessment, University of Kentucky. ALLEN, R.O., ROGERS, M.S, MITCHELL, R.S, and HOFFMAN, M.A., 1982. A Geochemical Approach to the Understanding of Ceramic 
Technology in Predynastic Egypt. Archaeometry, 24(2), 199-212.

ALLEN, R.O., 1989. Archaeological Implications of differences in the composition of Nile Sediments. In: R.O. Allen, ed. Archaeological Chemistry IV. Washington: American Chemical Society, pp. 33-56.

ALLEN, S., 2006. Miniature and model vessels in Ancient Egypt. In: M. Bárta, ed. The Old Kingdom Art and Archaeology. Proceedings of the conference held in Prague, May 31-4 June 2004. Prague: Czech Acedemy of Sciences, pp. 19-24.

ANDERSON, D., 1999. All that Glitters. The emergence of Native American Micaceous Art Pottery in Northern New Mexico. Tucson: School of American Research Press.

ARNOLD, D., 1993. Fascicle 1 Techniques and Traditions of Manufacture in the Pottery of Ancient Egypt. In: D. Arnold, and J. Bourriau, eds. An Introduction to Ancient Egyptian Pottery. Deutsches Archäologisches Institut, Abteilung Kairo. Mainz Am Rhein: Verlag Philipp Von Zabern.

BÁRTA, M., 1995. Pottery Inventory and the Beginning of the IVth Dynasty. Gottinger Mitteilungen, 149, 15-24.

BALDI, J., and ROUX, V., 2016. The innovation of the potter's wheel: a comparative perspective between Mesopotamia and the southern Levant. Levant, 48(3), 236-253. DOI: 10.1080/00758914.2016.1230379

BLOM-BÖER, I., 1994. Zusammensetzung altägyptischer Farbpigmente und ihre Herkunftslagerstätten in Zeit und Raum. OMRO, 74, 55-107.

BONNET, C., 1996. Kerma. Territoire et métropole. Cairo : IFAO.

BONNET, C., 1999. Aux origines de des Palais Kouchites. In: S. Wenig, ed. Studien zum antiken Sudan. Wiesbaden: Harrassowitz, pp. 484-494.

BONNET, C., 2008. The Town of Doukki Gel after the Last Archaeological Works. Kerma, 2006-7, 2007-8. Genava, 55, 183-246.

BONNET, C., and AHMED, S.EL-D.M., 1991. Un atelier de potiers d'époque napatéenne et quelques tombes chrétiennes. Genava : revue d'histoire de l'art et d'archéologie, 39, 25-28. DOI: 10.5169/ seals-728320

BOURRIAU, J., 1981. Umm el Ga'ab Pottery from the Nile Valley from before the Arab Conquest. Fitzwilliam Museum, Cambridge: Cambridge University Press.

BOURRIAU, J., 1995. Relations Between Egypt and Kerma During the Middle and New Kingdoms. In: W.V. Davies, ed. Egypt and Africa. Nubia from Prehistory to Islam. London: British Museum Press, pp. 129-144.

BOURRIAU, J., 2004. Egyptian Pottery found at Kerma Ancien, Kerma Moyen and Kerma Classique Graves at Kerma. In: T. Kendall, ed. Ninth International Conference of Nubian Studies. Boston: Museum of Fine Arts, Northeastern University, pp. 3-13.

BOURRIAU, J., SMITH, L.M.V., NICHOLSON, P.T., 2000a. New Kingdom pottery fabrics. Nile clay and mixed Nile/Marl clay fabrics from Memphis and Amarna. London: The Egypt Exploration Society.

BOURRIAU, J, NICHOLSON, P, ROSE, P., 2000b. Pottery. In: N. Nicholson, and I. Shaw, eds. Ancient Egyptian Material and Technology. Cambridge: Cambridge University Press, pp. 121-147.

BUAD, M., 2008. The Meroitic royal city of Muweis: first steps into an urban settlement of riverine Upper Nubia. Sudan \& Nubia, 12, 52-63.

BUDKA, J., 2016a. Beneath the golden hill... Across Borders blog. Blog of the ERC starting grant project AcrossBorders (ERC grant agreement $n^{\circ}$ 313668). Post written 11 Nov 2016 [viewed 29.01.2021]. Available from: https://acrossborders.oeaw.ac.at/beneath-the-golden-hill/

BUDKA, J. 2016b. Egyptian Cooking Pots from the Pharaonic Town of Sai Island, Nubia. Bulletin de liaison de la céramique égyptienne, 26, 285-295.

BUDKA, J., 2017. Pyramid Cemetery SAC5, Sai Island, Northern Sudan an update based on Fieldwork from 2015-2017. Ägypten und Levante/ Egypt and the Levant, 27, 107-130.

BUDKA, J., and DOYEN, F., 2013. Living in New Kingdom towns in Upper Nubia - New evidence from recent excavations on Sai Island. Ägypten und Levante/Egypt and the Levant, 22, 167-208.

CALOI, I., 2019. Breaking with Tradition? The Adoption of the Wheelthrowing Technique at Protopalatial Phaistos: Combining Macroscopic Analysis, Experimental Archaeology and Contextual Information. Annuario della Scuola Archeologica di Atene e delle Missioni Italiane in Oriente, 97, 9-25.

CARRANO, J. FERGUSON, J.R., GIRTY, G.H., SMITH, S.T. CARRANO, C.J., 2008. A Chemical and Mineralogical Comparison of Nubian and Egyptian Style Ceramics and the Implications for Culture Contact: Preliminary Report. Sudan and Nubia Bulletin, 12, 90-98.
CARRANO, J.L, GIRTY, G.H, and CARRANO, C.J., 2009. Re-examining the Egyptian colonial encounter in Nubia through a compositional, mineralogical, and textural comparison of ceramics. Journal of Archaeological Science, 36(3), 785-797.

CHARVÁT, P., 1981. The Mastaba of Ptahshepses. The Pottery. Prague: Charles University.

COURTY, M.A., and ROUX, V., 1995. Identification of Wheel Throwing on the basis of Ceramic Surface Features and Microfabrics. Journal of Archaeological Science, 22, 17-50.

DESSEL, J.P., 2009. Lahav I. Pottery and Politics: The Halif Terrace Site 101 and Egypt in the $4^{\text {th }}$ millennium BCE. Indiana: Eisenbrauns.

DOHERTY, S.K., 2015. The Origins and Use of the Potter's Wheel in ancient Egypt. Oxford: Archaeopress.

DOHERTY S.K., 2020. Investigating Dynastic Egyptian Pottery-Making: Archaeological and Ethnographical Considerations. In: A.K. Hodgkinson, and C. Lelek Tvetmarken, eds. Approaches to the Analysis of Production Activity at Archaeological Sites. Oxford: Archaeopress, pp. 122-140.

EDWARDS, D., 1999. Musawwarst Es Sufra III. A Meriotic Pottery Workshop at Musawwarat es Sufra. Wiesbaden: Otto Harrassowitz.

EDWARDS, D., 2004.The Nubian Past: An Archaeology of the Sudan. London: Taylor \& Francis.

EDWARDS, D., 2014. Early Meroitic Pottery and the creation of an early imperial culture? In: Der antike Sudan. Mitteilungen der Sudanarchäologischen Gesellschaft zu Berlin e.V. Sonderheft, Berlin: Sudanarchäologischen Gesellschaft zu Berlin, pp. 51-63.

EL-KHOULI, A., 1991. Meidum. The Australian Centre for Egyptology: Reports 3, Sydney: The Australian Centre for Egyptology.

EMERY, W., SMITH, H.S., and MILLARD, A., 1979. The Fortress of Buhen: The Archaeological Report. Excavations at Buhen, 1. EES EM, 49, London: Egypt Exploration Society.

D'ERCOLE, G., BUDKA, J., STERBA, J.H., GARCEA, E.A.A., and MADER, D., 2017. The Successful "recipe" for a long-lasting tradition: Nubian ceramic assemblages from Sai Island (northern Sudan) from prehistory to the New Kingdom. Antiquity, 91(355), 24-42. DOI: 10.15184/aqy.2016.262.

ERICSSON, K.A., and LEHMANN, A.C., 1996. Expert and exceptional performance: Evidence from maximal adaptation to task restraints. Annual Review of Psychology, 47, 273-305.

FAKHRY, A., 1961. The Monuments of Sneferu at Dashur. Vol II. The Valley Temple, Part II: The Finds. Cairo: General Organisation for Government Printing Office.

FALTINGS, D., 1998a. Canaanites at Buto in the early fourth millennium BC. Egyptian Archaeology, 13, 29-32.

FALTINGS, D., 1998b. Recent Excavations in Tell el-Fara'in/ Buto: New Finds and Their Chronological Implications. In: C.J. Eyre, ed. Proceedings of the $7^{\text {th }}$ International Congress of Egyptologists. Cambridge 3-9 September 1995. Leuven: Peeters. Orientalia Lovaniensia Analecta, pp. 365-375.

FREESTONE, I., and GAIMSTER, D., 1997. Pottery in the Making: World Ceramic Traditions. London: BM Press.

GARNETT, A., 2014. Making and Using Pottery. In: N. Spencer, A. Stevens, and M. Binder, eds. Amara West: Living in New Kingdom Nubia. London: British Museum, pp. 62-63.

GIBLI, J.D., and REMIGIUS, K., 2012. The social and symbolic context of the royal potters of Buganda, Azania, 47(1), 64-80.

GRATIEN, B., 1986. Sai I. La necropole Kerma. Paris: Centre National de la Recherche Scientifique Mission Archéologique Française au Soudan, Institut de Papyrologie et D'Egyptologie de L'Université de Lille.

GRATIEN, B., 2000. Les pots de caisson nubiens et les bols décorés de la première moitié du IIe millénaire avant J.-C. Cahiers Céramique Égyptienne, 6, 113-148.

GRAVES, C., 2010. Egyptian Imperialism in Nubia c. 2009-1191 $B C$. Unpublished thesis (PhD), University of Birmingham.

HOLTHOER, R., 1977. New Kingdom Pharaonic Sites. The Pottery. Lund: Esselte Studium.

HUMPHRIS, J., BUSSERT, R., ALSHISHANI, F., and SCHEIBNER, T., 2018. The ancient iron mines of Meroe. Azania: Archaeological Research in Africa, 53, 291-311.

JAMES, T.G.H., and APTED, M.R., 1953. The mastaba of Khentika called Ikhekhi. Archaeological survey of Egypt, $30^{\text {th }}$ memoir, London: Egypt Exploration Society. 
JANSSEN, J., 1975. Prolegomena to the Study of Egypt's Economic History during the New Kingdom. Studien zur Altägyptischen Kultur, 3, 127-185.

KINSMAN, D.J.J., 1967. Huntite from a carbonate-Evaporite Environment. American Mineralogist, 52, 1332-1340.

KNOBLAUCH, C., 2011. Not all that glitters: a case study of regional aspects of Egyptian Middle Kingdom pottery production in Lower Nubia and the second cataract. Cahiers de la Céramique égyptienne, 9, 167-183.

KNOBLAUCH, C., 2019. Middle Kingdom Fortresses. In: D. Raue, ed. Handbook of Ancient Nubia. Berlin and Boston: De Gruyter.

KUHRT, A., 1995. The Ancient Near East, c3000-300 BC (Vol. 1). London and New York: Routledge Press.

LACOVARA, P., 1997. Egypt and Nubia during the Second Intermediate Period. In: E.D. Oren, ed. The Hyksos. New Historical and Archaeological Perspectives. Proceedings of the International Seminar on Cultural Interconnections in the Ancient Near East, held at the University of Pennsylvania, Museum of Archaeology and Anthropology, JanuaryApril 1992. University Museum Monograph, 96. University Museum Symposium Series, 8. Philadelphia: University of Pennsylvania Museum, pp. 69-83.

LEE, L., and QUIRKE, S., 2000. Painting Materials. In: P.T. Nicholson, and I. Shaw, ed. Ancient Egyptian materials and technology. Cambridge: Cambridge University Press, pp. 104-120.

LENOBLE, P., SHARIF, N.M., 1992. Barbarians at the gates? The royal mounds of El Hobagi and the end of Meroe. Antiquity, 66, 626-635.

NÄSER, C., 2010a. Le grand enclos de Moussawarrat es-Soufra: une énigme monumentale. In: M. Baud, ed. Méroé. Un empire sur le Nil. Paris and Milan: Officina Libraria, pp. 225-226.

NÄSER, C., 2010b. Moussawarat es-Soufra, une énigme monumentale de la période méroïtique. In: Méroé, un empire sur le Nil aux confins de multiples cultures. Dossiers d'Archéologie hors-série, 18, pp. 20-25.

NEWBERRY, P., 1893. Beni Hasan. Part 1, Archaeological Survey of Egypt. London: Paul Kegan.

NORDSTRÖM, H., and BOURRIAU, J., 1993. The Vienna System. In: D. Arnold, and J. Bourriau, eds. Ceramic technology: clays and fabrics, Fascicle 2, an introduction to ancient Egyptian pottery. Deutsches Archäologisches Institut, Abteilung Kairo, Sonderschrift 17, Mainz am Rhein: Philipp von Zabern, pp. 168-182.

O'CONNOR, D., 1991. Early States along the Nubian Nile. In: W.D. Davies, ed. Egypt and Africa. London: Routledge.

O'CONNOR, D., 1993. Ancient Nubia: Egypt's Rival in Africa. Philadelphia: University Museum.

PAPAZIAN, H., 2005. Domain of the Pharaoh: The Structure and Components of the Economy of the Old Kingdom. Unpublished thesis (PhD), University of Chicago.

PERTHUISOT, J.P., 1971. Présence de magnésite et de huntite dans le sebkha el Melah de Zarzis. Comptes Rendus des Séances de l'Académie des Sciences de Paris, Série D, 272, 185-188.

PETRIE, W.M.F., 1892. Medum. London: David Nutt, Strand.

PETRIE, W.M.F., MACKAY, E., WAINWRIGHT, G., 1910. Meydum and Memphis III. London: British School of Archaeology in Egypt and Egyptian Research Account, UCL and Bernard Quaritch.

PIERRET, A., 1995. Analyse technologique des céramiques archéologiques: développements méthodologiques pour l'identification des techniques de façonnage. Un exemple d'application: le matériel du village des Arènes à Levroux (Indre). Paris: Université de Paris I Sorbonne.

POLLOCK, S., 1999. Ancient Mesopotamia: The Eden that Never Was. Cambridge: Cambridge University Press.

POWELL, C., 1995. The Nature and Use of Ancient Egyptian Potter's Wheels. Amarna Reports, 6, 309-335.

RICE, P.M., 1987. Pottery Analysis, a Sourcebook, Chicago and London: The University of Chicago Press.

REISNER, G.A., 1931. Mycerinus: The Temples of the Third Pyramid at Giza. Cambridge, MA: Harvard University Press.

ROBERTSON, J.H., and HILL, E.M., 1999. Two traditions or one? New interpretation of the hand- made/wheel-made ceramics from Meroe. In: D. Welsby, ed. Recent Research in Kushite History and Archaeology. London: British Museum, pp. 321-330.

ROSE, P., 2012. Early $18^{\text {th }}$ Dynasty Nubian Pottery from the site of Sesebi, Sudan. In: I. Forstner-Müller, and P. Rose, eds. Nubian pottery from Egyptian cultural contexts of the middle and early New Kingdom, Proceedings of a Workshop held at the Austrian Archaeological Institute at Cairo, 1-12 December 2010. Vienna: Austrian Archaeological Institute, pp. 13-29.

ROSE, P., 1998. The Meroitic pottery. In: D.N. Edwards, ed. Gabati. A Meroitic, Post-Meroitic and Medieval cemetery in Central Sudan. Volume 1. Sudan Archaeological Research Society Publication, 3, British Archaeological Reports, International Series, 740. London and Oxford: BAR Publishing, pp.138-177.

ROSE, P.J., 2019. Early Kushite Ceramics of the Earlier $1^{\text {st }}$ Millennium BC in Lower and Upper Nubia. In: D. Raue, ed. Handbook of Ancient Nubia. Berlin and Boston: De Gruyter.

ROSS, J., FOWLER, K.D, SHAI, I., GREENFIELD, H.J, MAEIR, A.M., 2018. A scanning method for the identification of pottery forming techniques at the mesoscopic scale: A pilot study in the manufacture of Early Bronze Age III holemouth jars and platters from Tell es-Safi/Gath. Journal of Archaeological Science: Reports, 18, 551-561.

ROUX, V., 1994. La technique du tournage: définition et reconnaissance par les macrotraces. In: D. Binder, and J. Courtin, eds. Terre cuite et société. La céramique, document technique, économique, culturel. Juan-les-Pins: Editions APDCA, pp. 45-58.

ROUX, V., 2008. Evolutionary Trajectories of Technological Traits and Cultural Transmission: A Qualitative Approach to the Emergence and Disappearance of the Ceramic Wheel-fashioning Technique in the Southern Levant. In: M. Stark, B. Bowser, and L. Horne, eds. Cultural Transmission and Material Culture. Breaking Down Boundaries. Tuscon: Arizona University Press, pp. 82-104.

ROUX, V., 2009. Wheel Fashioned Ceramic Production during the Third Millennium BCE in the Southern Levant: A Perspective from Tell Yarmuth. In: S.A. Rosen, and V. Roux, eds. Techniques and People: Anthropological Perspectives in the Archaeology of Proto-Historic and Early Historic Periods in the Southern Levant. Paris: De Boccard, pp. 195-212.

ROUX, V., and DE MIROSCHEDJI, P., 2009. Revisiting the History of the Potter's Wheel in the Southern Levant. Levant, 41(2), 155-173.

ROUX, V., and CORBETTA, D., 1989. The Potter's Wheel: Craft Specialization and Technical Competence. Oxford: Oxford \& IBH Publishing.

ROUX, V., and COURTY, M.A., 1997. Les bols élaborés au tour d'Abu Hamid: rupture technique au 4emill. avt J.-C. dans le Levant sud. Paléorient, 23, 25-43.

ROUX, V., and COURTY, M.-A., 1998. Identification of Wheel-fashioning methods: Technological Analysis of $4^{\text {th }}-3^{\text {rd }}$ millennium BC Oriental Ceramics. Journal of Archaeological Science, 25, 747-763.

SÄVE-SÖDERBURG, T., 1963. Archaeological Investigations between Faras and Gemai, November 1962-March 1963. Kush, 2, 47-99.

SIMPSON, S.J., 1997. Early Urban Ceramic Industries in Mesopotamia. In: D. Gaimster, and I. Freestone, eds. Pottery in the Making: Early Ceramic Traditions. London: British Museum Press, pp. 50-55.

SHAW, I., 2004. Identity and Occupation. How did individuals define themselves and their work in the Egyptian New Kingdom? In: J. Bourriau, and J. Phillips, eds. Invention and Innovation. The Social Context of Technological Change 2: Egypt, the Aegean, and the Near East. 1650$1150 B C E$. London and Oxford: Oxbow Books, pp. 12-24.

SMITH, H., 1976. The Fortress of Buhen: The Inscriptions. Excavations at Buhen, 2. EES EM, 48, London: Egypt Exploration Society.

SMITH, S.T., 1995. Askut in Nubia: The Economics and Ideology of Egyptian Imperialism in the Second Millennium BC. London and Cambridge: Cambridge University Press.

SMITH, S.T., 2002. Pots and Politics: Ceramics from Askut and Egyptian Colonialism during the Middle through New Kingdoms. In: C.A. Redmount, and C.A. Keller, eds. Egyptian Pottery, Proceedings of the 1990 Pottery Symposium at the University of California. University of California Publications in Egyptian Archaeology, 8. Berkeley: University of California, pp. 43-79.

SMITH, S.T., 2014. A Potter's Wheelhead from Askut and the Organization of the Egyptian Ceramic Industry in Nubia. Journal of the American Research Center in Egypt, 50, 103-121. DOI: 10.5913/jarce.50.2014. $\mathrm{a} 018$

SPATARO, M., MILLET, M., and SPENCER, N., 2014. The New Kingdom settlement of Amara West (Nubia, Sudan): mineralogical and chemical investigation of the ceramics. Archaeological and Anthropological Sciences, 7, 399-421. 
SPENCER, N., 2014. Amara West: considerations on urban life in occupied Kush. In: J.R. Anderson, and D.A. Welsby, eds. The Fourth Cataract and Beyond. Proceedings of the $12^{\text {th }}$ International Conference for Nubian Studies. British Museum Publications on Egypt and Sudan, 1, Leuven: British Museum, pp. 457- 485.

SPENCER, N., STEVENS, A., and BINDER, M., eds., 2014. Amara West: Living in New Kingdom Nubia. London: British Museum.

SPENCER, N., 2017. Building on new ground: the foundation of a colonial centre at Amara West. In: N. Spencer, A. Stevens, and M. Binder, eds. The New Kingdom in Nubia: lived experience, pharaonic control and indigenous traditions. British Museum Publications on Egypt and Sudan, 3. Peeters, Leuven, Paris and Walpole MA: British Museum, pp. 321353.

SPENCER, P., 2002. Amara West, II: The cemetery and the pottery corpus Excavation Memoir, 69. London: Egypt Exploration Society.

THÉR, R., 2020. Ceramic technology. How to reconstruct and describe pottery-forming practices. Archaeological and Anthropological Sciences, 12(8), 17-50

TING, C., and HUMPHRIS, J. 2020. Pottery Production in Ancient Sudan: A Case Study of the Pottery from the Slag Heaps of Meroe and Hamadab. In: A. K. Hodgkinson, and C. Lelek Tvetmarken, eds. Approaches to the Analysis of Production Activity at Archaeological Sites. Oxford: Archaeopress, p.122-140.

VANDER KOOIJ, G., 2002. The Potters of el-Fustat (Cairo) and el-Nazla (Fayoum). In: G. Vander Kooij, and W.Z. Wendrich, eds. Moving Matters, Ethnoarchaeology in the Near East. Leiden: University of Leiden, pp. $147-158$.

VAN DER LEEUW, S., 2002. Giving the potter a choice, conceptual aspects of pottery techniques. In: P. Lemonnier, ed. Technological Choices Transformations in material culture since the Neolithic. London: Routledge Press, pp. 238-288.
VERCOUTTER, J., 1966. Trois campagnes de fouilles à Mirgissa en Nubie soudanaise (1963-1966). Comptes rendus des séances de l'Académie des Inscriptions et Belles-Lettres, 110(2), 276-283. DOI: 10.3406/ crai.1966.11979

VERCOUTTER, J., 1970. Mirgissa. Paris: Direction générale des relations culturelles, scientifiques et techniques.

VERNER, M., 1992. The Discovery of a Potter's Workshop in the Pyramid Complex of Khentkaus at Abusir. Cahiers de la Céramique de la Égyptienne, 3 (3), 55-59.

VILA, A., 1987. Le cimitière kermaique d'Ukma Ouest. Paris: CNRS.

WELSBY, D.A., 2001. Excavations within the Pharaonic and Kushite site at Kawa and in its Hinterland, 2000-2001. Sudan \& Nubia, 5, 64-70.

WELSBY-SJÖSTRÖM., I., and THOMAS, R.I., 2011. The Kushite pottery sequence at Kawa: Parallels at home and abroad. Sudan \& Nubia, 15, 64-71.

WILliAMS, B., 2017. The New Kingdom town at Serra East and its cemetery. In: N. Spencer, A. Stevens, and M. Binder, eds. The New Kingdom in Nubia: lived experience, pharaonic control and indigenous traditions. British Museum Publications on Egypt and Sudan, 3. Peeters, Leuven, Paris and Walpole MA: British Museum, pp. 309-322.

WILliAMS, B., HUGHES, G.R., and KNUDSTAD, J.W., 1993. Excavations at Serra East: parts 1-5, A-Group, C-Group, Pan Grave, New Kingdom, and $X$-Group remains from cemeteries $A-G$ and rock shelters. Chicago: Oriental Institute of the University of Chicago.

WODZIŃSKA, A., 2009. A Manual of Egyptian Pottery: Naqada III Middle Kingdom (Vol. II). London: Ancient Egypt Research Associates - Oxbow Books.

WOLF, P., NOWOTNICK, U., 2006. Hamadab - a Meroitic Urban Settlement. Excavations 2001-2003. Archeologie du Nil Moyen, 10, 257-272. 
